\title{
FIGO Stage IC3 Ovarian Cancer
}

National Cancer Institute

\section{Source}

National Cancer Institute. FlGO Stage IC3 Ovarian Cancer. NCI Thesaurus. Code C128084.

Stage IC ovarian cancer with malignant cells in the ascites or peritoneal washings. (FIGO, 2014) 